\title{
JOURNAL.RU
}

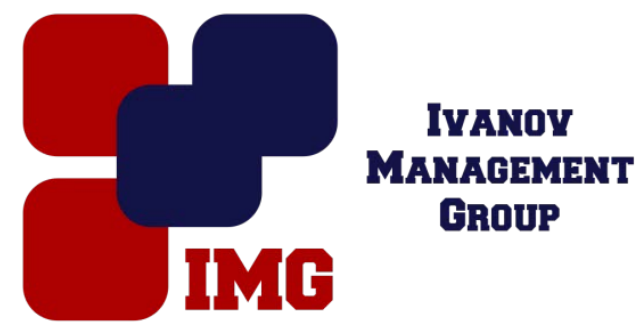

Мусабеков О.У. $A O$ «Алматинский технологический университет» Алматы, Республика Казахстан

doi: 10.18411/lj-30-11-2016-3-11

idsp 000001:lj-30-11-2016-3-11

\section{Исследовательские задачи в обучении физике студентов технических вузов}

\section{Аннотация}

Статья посвящена проблеме повышения качества подготовки выпускников технических вузов. Решение проблемы рассматривается в статье через реализацию исследовательского подхода в рассмотрении сущности физических задач. В статье рассмотриваются роли исследовательских задач по физике как в развитии творческого мышления, так и в целом в развитии личности будущего инженера.

Ключевые слова: функции исследовательских задач по физике, типы исследовательских задач по физике,исследовательская задача, задача, компетентный инженер.

Keywords: functions of research tasks on physics, types of research tasks on physics, research task, task, competent engineer.

Формирование у студентов исследовательских умений способно обеспечить им в условиях структурного и качественного усложнения профессиональной деятельности квалификационный рост и профессиональную мобильность. Инженеры испытывают существенные затруднения в ходе решения комплекса исследовательских задач и во многих случаях демонстрируют слабую готовность к исследовательской деятельности. Однако, несмотря на существенный интерес ученых к данной проблеме и значительные результаты, полученные к настоящему времени, проблема готовности будущих инженеров к исследовательской деятельности по-прежнему в достаточной степени не решена [1]

Исследовательская деятельность рассматривается нами как базирующаяся на научной методологии деятельность субъекта образовательного процесса по получению нового, научно обоснованного знания. Систему формирования у студентов готовности к исследовательской деятельности мы рассматриваем как функциональную подсистему образовательной системы инженерного вуза. 
Инженерная деятельность тесно переплетается с наукой, опираясь на постулаты фундаментальной науки и результаты прикладных исследований. В этом смысле оно является отраслью научно-технической деятельности.

Э. Крик пишет: «... инженерное дело-это решение инженерных задач ...Задача возникает всякий раз, когда нужно перейти от одного состояния к другому. ... если нет различных способов достижения требуемого результата, то нет и инженерной задачи.Точно так же если все возможные решения одинаково хороши, то инженерной задачи не существует» [2, с. 6]. Следовательно, исследовательская деятельность инженера -это решение инженерных исследовательских задачпо получению нового, научно обоснованного знания.

Учебные задачи физики, связанные с исследованием и изобретательностью (конструированием) называются творческими задачами. При составлении творческих физических задач нужно учитывать, что«в науке различают в основном два вида творчества: открытия иизобретения». Поэтому творческие задачи по физикеусловно можно разделить наисследовательские и конструкторские. Первые отвечают на вопрос: почему такпроисходит? вторые на вопрос: как это сделать? [3, с.45].

При обучении студентов с помощью решения задач можно воспитывать и выявлять творческое научное мышление. Хорошо известно, что для плодотворной научной работы требуются не только знание и понимание, но, главное, еще самостоятельное аналитическое и творческое мышление. Как одно из эффективных средств воспитания, выявления и оценки этих качеств при обучении будущих инженеров П.Л. Капица составил задачи [4, с.3-4]. Он стремился осуществить эту цель, составляя большинство задач таким образом, что они являются постановкой небольших проблем, и студент должен на основании известных физических законов проанализировать и количественно описать заданное явление природы. Эти явления природы выбраны так, чтобы они имели либо научный, либо практический интерес, и при этом П.Л. Капица учитывал, что уровень знаний студентов должен быть достаточным, чтобы выполнить задание.

Задача - есть первое приближение к небольшой научной работе. Решение этих задач - уже какое-то определенное исследование. Студент может показать при решении задач свои знания и свое понимание физики в самых разных степенях. Все эти задачи составлены так, что студент их может и в двух-трех словах приблизительно решить и, углубляясь дальше, до неограниченного предела. Иследовательские задачи по физике являются одним из средств профессионального обучения.Производственный материал курсафизики можно условно подразделить на две части. Первая часть заключает в себе тенденции современного производства и их научное обоснование. Эта часть нашла свое место в курсе физики. Студенты в соответствующих разделах знакомятся с принципами механизации, теплофикации, электрификации и автоматизациипроизводства. Иследовательские задачи по первой части можно составлять на основе межпредметной связи физики и общетехнических 
дисциплин. Например,почему для получения больших мощностей на практике пользуются электромагнитными, а не электрофорными машинами?

Другую часть производственного материала составляют конкретные технические применения законов физики. Иследовательские задачи по второй части можно составлять на основе межпредметной связи физики и профилирующих (спкциальных) дисциплин. Например,следующие задачи.Почему нельзя увеличить шаг винта слесарных тисков? Почему частицы красителя очень долго не осаждаются на дно банки, хотя удельный вес этих частиц значительно больше удельного веса растворителя?

По И.Я. Лернеру, основными чертами творческой деятельности являются: самостоятельный перенос знаний и умений в новую ситуацию; видение новых проблем в знакомых стандартных условиях; видение новой функции знакомого объекта; видение структуры объекта, подлежащего изучению; умение видеть альтернативу решения; умение комбинировать ранее известные способы решения проблемы в новый способ; умение создавать оригинальный способ решения при известных других [5, с.12-15].

В зависимости от профиля подготовки студентов каждый из видов творческой деятельности наполняется конкретным содержанием, однако, основные черты этой деятельности более стабильные, чем знания, умения и навыки. Поэтому обучение студентов технических вузов решению исследовательских задач по физике связано с действиями: самостоятельный перенос знаний и умений по физике в профессиональную ситуацию; видение физических способов решения проблем в знакомых стандартных условиях производства; видение структуры технического устройства или технологического процесса с точки зрения физики; комбинировать ранее известные способы решения технических проблем в новый способ на основе физических знаний; на базе физических знаний и методовсоздавать оригинальный способ решения технических задач при известных других.

Как показал наш педагогический эксперимент по обучению студентов технических вузов решению исследовательских задач физикипо вышеуказанной системе действий развивает их творческие способности, повышает интерес к решению профессиональных задач. 


\section{Литература}

1. Горшкова О.О. Деятельностный подход к построению системы подготовки бкдущих инженеров к исследовательской деятельности // Фундаментальные исследования. - 2012. - № 3. - С. 25-28;

2. Крик Э. Введение в инженерное дело. Пер. с англ. М., «Энергия», 1970. 176 c

3. Разумовский В.Г. Творческие задачи по физике. - М.: Просвещение, 1966. $156 \mathrm{c}$.

4. Капица П.Л. Понимаете ли вы физику? - М.: Знание, 1966. - 94 с.

5. ЛернерИ.Я. Проблемное обучение. - М.: Педагогика, 1974. - С. 128. 